$\mathrm{P}$

ациональная противомикробная терапия больных пиодермиями

\author{
Г. Н. Михеев ${ }^{1}$, Е. В. Соколовский ${ }^{1}$, А. М. Савичева ${ }^{2}$
}

1 ФГБОУ ПО «Первый Санкт-Петербургский государственный медицинский университет им. академика И.П. Павлова» Минздрава России

197022, г. Санкт-Петербург, ул. Льва Толстого, д. 6/8

${ }^{2}$ ФГБНУ «НИИ акушерства, гинекологии и репродуктологии им. Д. О. Отта» СЗО РАМН

199034, г. Санкт-Петербург, Менделеевская линия, д. 3

\begin{abstract}
Приведены сведения из истории открытия и развития противомикробной терапии в XX и начале XXI столетия.
Представлены данные о фармакологическом действии антибактериальных препаратов из разных групп,

применяющихся для лечения больных пиодермией, режимах их дозирования, фрармакокинетике, побочных действиях, противопоказаниях, лекарственном взаимодействии. Выделены основные фракторы, приводящие к формированию резистентных штаммов микроорганизмов. На примере амоксициллина + клавулановой кислоты, джозамицина и доксициклина моногидрата показаны преимущества антибиотиков с широким спектром противомикробного действия при лечении больных пиодермией. Представлены доводы, обосновывающие необходимость отказа от эмпирического назначения антибактериальной терапии. Для выбора рациональной этиотропной стартовой терапии больных пиодермией необходимо использовать результаты микробиологического исследования этиологии и чувствительности патогенной микробной фрлоры к противомикробным препаратам.
\end{abstract}

Ключевые слова: пиодермия, резистентность микроорганизмов, рациональная антибактериальная терапия.

Контактная информация: s40@mail.ru. Вестник дерматологии и венерологии 2017; (1): 68—75.

\title{
Reasonable antimicrobial therapy in patients with pyodermatosis
}

G. N. Miheev' ${ }^{1}$, E. V. Sokolovskij ${ }^{1}$, A. M. Savicheva ${ }^{2}$

${ }^{1}$ Pavlov State Medical University of St. Peterburg

L. Tolstogo str., 6-8, St. Petersburg, 197022, Russia

${ }^{2}$ FSBSI "The Research Institute of Obstetrics, Gynecology and Reproductology named after D.0. Ott" Mendeleyevskaya line, 3, St. Petersburg, 199034, Russia

\begin{abstract}
The data are given about the history of the invention and development of antimicrobial therapy in the XX-th and the beginning of the XXI-th centuries. There are presented data on the pharmacological effects of antibacterial agents from different groups that are used for the treatment of patients with pyodermatosis, dose schedules, pharmacokinetics, adverse effects, contraindications, and medicine interactions. The main causes leading to the formation of resistant microorganism strains are pointed. Advances of broadspectrum antibacterial antibiotics for treatment the pyodermic patients are demonstrated on the example of amoxicillin+clavulinic acid, josamycin and doxycycline monohydrate. The arguments justifying the need to refuse empiric administration of antibacterial therapy are presented. To select a rational causal initial therapy of patients with pyoderma it is necessary to use the results of microbiological study of etiology and pathogenic microflora sensitivity to antimicrobial preparations.
\end{abstract}

Key words: pyodermatosis, resistance of microorganisms, rational antibacterial therapy. 
Пиодермии - самые частые инфрекционные поражения кожи. Их причиной чаще всего являются стафрилококки и стрептококки как по отдельности, так и в сочетании. Это связано с постоянным наличием их в окружающей среде и на поверхности кожи человека. Кожа на своей поверхности имеет такие бактерии, как эпидермальные стафилококки, дифтероиды (Corynebacterium и Brevibacterium) и анаэробные палочки (Propionibacterium). Эти микроорганизмы играют защитную роль за счет способности производить свободные жирные кислоты, токсичные для многих бактерий, что способствует колонизационной резистентности кожи. Наиболее важным патогеном для кожи является золотистый стафилококк (Staphylococcus aureus). Примерно 60\% здоровых людей имеют золотистый стафилококк на поверхности кожи и видимой слизистой оболочки. Что касается стрептококков, то они часто колонизируют желудочно-кишечный тракт, однако только в $1 \%$ случаев стрептококки колонизируют поверхность кожи [1]. В последние десятилетия помимо стафилококков и стрептококков стали обнаруживать и другие возбудители гнойного воспаления кожи: энтерококки (Enterococcus spp.), грамотрицательные палочки (Proteus spp., Eschericia coli, Pseudomonas aeruginosa и некоторые другие). Эти микроорганизмы, как самостоятельно, так и в ассоциации, являются обычно возбудителями нозокомиальной инфекции и выделяются в случаях внутрибольничного инфицирования тяжелобольных [2-5]. Внедрению в кожу пиогенных возбудителей и возникновению пиодермии способствуют экзогенные и эндогенные фракторы, которые нарушают барьерную фуункцию кожи.

К экзогенным фракторам относятся: 1) микро- и макротравмы кожи, расчесы, уколы, потертости, порезы, укусы насекомых и пр.; 2) мацерация рогового слоя в результате повышенной потливости, воздействия влаги и пр.; 3) общее и местное переохлаждение и перегревание; 4) загрязнение кожи, как бытовое (нарушение норм гигиены), так и профессиональное (смазочные масла, горючие жидкости, растворители, грубые пылевые частицы угля, цемента, металлов, земли, извести и пр.). К эндогенным факторам относятся: 1) существование в организме очагов хронической инфекции (лор-патология, одонтогенная, урогенитальная хроническая патологии и пр.); 2) эндокринные заболевания (сахарный диабет, гиперкортицизм, гиперандрогения и пр.); 3) хроническая интоксикация (алкоголизм, наркомания и др.); 4) нарушения питания (гиповитаминоз, недостаточность белка); 5) иммунодефицитные состояния (длительное лечение глюкокортикоидными гормонами, иммунодепрессантами; ВИЧ/СПИД-инфекция, лучевая терапия и пр.).

Все перечисленные выше фракторы в конечном итоге приводят к нарушению клеточного и гуморального звеньев иммунитета, вследствие чего снижается защитная фрункция кожи. Это приводит к изменению ко- личества и состава микрофрлоры на поверхности кожи с преобладанием условно-патогенных микроорганизмов. Различные формы пиодермии могут возникать первично на ранее не измененной коже, а также вторично на фоне существующих поражений кожи. Чаще всего это зудящие дерматозы (чесотка, вшивость, атопический дерматит, экзема), а также заболевания, сопровождающиеся значительным нарушением целостности эпидермиса и дермы (пузырчатка, трофическая язва голеней, ожоговый дерматит 2-3-й степени и др.), предрасполагающие к осложнению пиодермией.

Этиотропная терапия является самой важной в лечении больных пиодермией. Именно рациональная противомикробная терапия предотвращает прогрессирование и распространение очагов пиогенной инфекции, появление разнообразных ее осложнений. При острых поверхностных ограниченных очагах пиодермии (импетиго, фолликулит, паронихия и др.) лечение может быть ограничено наружным применением антибиотика или антисептика. Во всех иных случаях необходимо проводить системную антибактериальную терапию. Показаниями для назначения системной антибактериальной терапии являются: 1) множественная пиодермия, ее быстрое распространение по кожному покрову, отсутствие положительного результата от наружной терапии; 2) появление увеличенных и болезненных регионарных лимфатических узлов или лимфангита; 3) наличие общей реакции организма на гнойное воспаление (повышение температуры тела, озноб, недомогание, слабость и пр.); 4) глубокие неосложненные и особенно осложненные пиодермии с локализацией на лице (угроза лимфо- и гематогенной диссеминации инфекции, вплоть до тромбоза венозных синусов мозга и развития гнойного менингита); 5) относительным показанием (решение принимают в каждом конкретном случае по совокупности клинических данных) является наличие даже ограниченных поверхностных фрорм пиодермиии у ослабленных больных на фоне иммуносупрессивной, лучевой терапии, у ВИЧ-инфицированных, у больных с эндокринной или гематологической патологией.

Системная антибактериальная терапия может проводиться препаратами из различных групп антибиотиков. Обширный арсенал противомикробных препаратов создавался с 1935 г., когда бактериолог Г. Домагк ввел в медицину первый сульфаниламидный препарат пронтозил, или красный стрептоцид, обладавший выраженным антибактериальным свойством. В 1928 г. А. Флеминг обнаружил, что штамм плесени Penicillium notatum выделяет вещество, оказывающее мощное антибактериальное действие. Он опубликовал об этом работу и назвал вещество, оказывающее мощное подавляющее действие на микробы, пенициллином. В 1939 г. биохимик Э.Б. Чейни и патолог Х.У. Флори выделили пенициллин в чистом виде, что сделало возможным его первое применение в 1941 г. при бактериальных 
инфекциях у раненых военнослужащих с прекрасными результатами. В 1945 г. А. Флемингу, Х.У. Флори и Э. Чейну, как и Г. Домагку в 1939 г. за обнаружение антибактериального действия красного стрептоцида, была вручена Нобелевская премия за открытие пенициллина и его лечебного действия. Так начиналась история антибиотиков - великого открытия XX века в области медицины. Однако вскоре после окончания Второй мировой войны появились первые сообщения о случаях госпитальной инфекции, вызванных устойчивыми к пенициллину разновидностями золотистого стафилококка. Вслед за этим появились сообщения и о других микроорганизмах, устойчивых к пенициллину. Так, пенициллин, подавляя многие виды грамположительных бактерий, одновременно привел к появлению резистентных к пенициллину штаммов этих же бактерий. Оказалось, что со временем (быстро или медленно) любой вид бактерий может вырабатывать резистентность к любому противомикробному препарату. Само воздействие противомикробного препарата на бактерии (создание неблагоприятных условий для их существования) не только приводит к массовой их гибели, но также стимулирует включение механизмов приспособления к неблагоприятным условиям внешней среды, что позволяет сохраниться отдельным бактериям (появляется резистентный к антимикробному препарату штамм бактерии).

В настоящее время возбудители пиогенной инфекции приобрели устойчивость к разным антибиотикам и антибактериальным химиотерапевтическим препаратам. Выделяются новые штаммы микроорганизмов, нечувствительных к ряду антибиотиков. Во всех странах мира феномен резистентности микроорганизмов к антибактериальным препаратам стал основной проблемой при их применении. В последние годы в ряде стран стремительно растет резистентность Klebsiella pneumoniae к цефралоспоринам III поколения, фрторхинолонам, аминогликозидам и карбапенемам. Вызывают тревогу и данные о резистентности Staphylococcus aureus к метициллину [6, 7]. Распространение таких полирезистентных штаммов микроорганизмов представляет грозную реальность. Разработка и внедрение нового антибиотика занимает более 10 лет, а резистентность к нему у бактерий развивается гораздо быстрее. В связи с этим угроза потерять контроль над инфекционными заболеваниями стала вполне реальной. У подавляющего большинства микроорганизмов встречаются $\beta$-лактамазы: они встречаются у 60-80\% штаммов стафилококков. У грамотрицательных бактерий, в том числе среди штаммов E. coli, встречаются $\beta$-лактамазы расширенного спектра (БЛРС). Исключение составляют стрептококки, не продуцирующие $\beta$-лактамазы.

Наиболее распространенным механизмом устойчивости микроорганизмов к $\beta$-лактамным антибиотикам (пенициллины, цефалоспорины) является их ферментативная инактивация в результате гидроли- за одной из связей $\beta$-лактамного кольца фрерментами $\beta$-лактамазами. Плазмидная, или хромосомная, локализация генов, кодирующих резистентность, способствует быстрому внутри- и межвидовому формированию и распространению устойчивости к антибиотикам. Плазмидные БЛРС грамотрицательных бактерий способны разрушать цефалоспорины III поколения. Рутинные методы определения анибиотикочувствительности часто не выявляют этот механизм устойчивости. Чаще всего БЛРС встречаются у микроорганизмов рода Klebsiella, достаточно часто у E. coli и Proteus spp., реже у других грамотрицательных бактерий. В нашей стране частота распространенности этих ферментов среди клебсиелл достигает в некоторых учреждениях 90\%. При гиперпродукции хромосомных $\beta$-лактамаз, особенно при тяжелых нозокомиальных инфекциях, вызванных Enterobacter spp., Citrobacter spp. и некоторыми другими микроорганизмами, в процессе лечения цефалоспоринами III поколения примерно в 20\% случаев фрормируется резистентность к этим антибиотикам. В большинстве $\beta$-лактамных антибиотиков в настоящее время используются ингибиторы $\beta$-лактамаз, такие как клавулановая кислота, сульбактам, тазобактам. Ряд микроорганизмов уже начинают вырабатывать резистентность и к этим ингибиторам. Хромосомные $\beta$-лактамазы класса $B$, разрушающие карбапенемы, распространены среди редких видов микроорганизмов, например S. maltophilia [8, 9].

Основным механизмом формирования устойчивости микроорганизмов к аминогликозидам является их ферментативная инактивация. Для нашей страны характерна высокая частота распространения устойчивости среди грамотрицательных бактерий к гентамицину и тобрамицину, что, вероятно, связано с необоснованно широким применением гентамицина. Частота устойчивости к нетилмицину несколько ниже. Устойчивость к амикацину встречается достаточно редко. Ведущим механизмом устойчивости к хинолонам/фрторхинолонам является модификация (изменение структуры) двух бактериальных ферментов ДНК-гиразы и топоизомеразы IV, опосредующих конформационные изменения в молекуле бактериальной ДНК, необходимые для ее нормальной репликации. Каждый из ферментов состоит из четырех субъединиц. ДНК-гираза состоит из двух gyrA и двух gyrВ субъединиц (соответствующие гены gyrA и gyrB), топоизомераза IV — из субъединиц parC и parE (соответствующие гены parC и parE). Гены обоих ферментов локализованы на бактериальной хромосоме [10]. Устойчивость к фрторхинолонам (ципрофлоксацину и офлоксацину) является реальной проблемой при лечении нозокомиальных инфекций. Быстрее всего резистентность фрормируется у штаммов $P$. aeruginosa. Появляются данные о росте устойчивости к фрторхинолонам среди пневмококков. Основной мишенью действия макролидов, кетолидов и линкозамидов является 50S-субъединица бакте- 
риальной рибосомы. Несмотря на различия в структуре, все эти антибиотики имеют общий участок связывания с рибосомой. У большинства бактерий устойчивость возникает в результате метилирования 23S-субъединицы рPHK. Известно около 20 генов (erm - erythromycin ribosome methylation), кодирующих фермент метилазу, они ассоциированы с транспозонами и могут локализоваться как на плазмидах, так и на хромосомах. Метилазы широко распространены среди многих аэробных и анаэробных грамположительных и грамотрицательных бактерий. Устойчивость к макролидам и линкозамидам распространена среди метициллинорезистентных стафилококков. Среди метициллиночувствительных стафилококков частота устойчивости не превышает $10 \%$.

Детерминанты резистентности к тетрациклинам обычно локализованы на плазмидах, что обеспечивает их быстрое внутри- и межвидовое распространение Часть генов и соответствующие белки (TetA - TetE) распространены среди грамотрицательных бактерий, другие (TetK, TetL) - среди грамположительных. Устойчивость энтеробактерий, особенно Klebsiella pneumoniae и E. coli, к карбапенемам (имипенем и меропенем) является новой проблемой во всем мире. Механизм устойчивости к этим антибактериальным препаратам заключается в продукции микроорганизмами карбапенемаз [11].

С учетом мирового и отечественного опыта по оптимизации антибактериальной терапии больных в многопрофильных стационарах предлагается выполнять ряд организационных и клинических мероприятий по улучшению практики назначения антибактериальных препаратов $[5,12,14,15]$. В частности, чтобы повысить эффективность антибактериальной терапии больных и замедлить появление резистентных штаммов бактерий, необходимо придерживаться определенных правил. Так, назначение антимикробного препарата пациенту без верифицированного диагноза или при несоответствующей нозологии, без учета чувствительности возбудителя к антибактериальным средствам, недостаточные дозы препарата или длительность лечения, игнорирование рекомендованной кратности его введения и возможности взаимодействия с другими лекарственными средствами снижают его активность, приводят к фрормированию резистентных штаммов патогенных микроорганизмов и ухудшают прогноз заболевания [12-15].

До сих пор сохраняется эмпирический выбор антибактериального препарата не только в амбулаторной практике, но и в больничных условиях. Обычно это происходит в связи с тем, что врач сталкивается с необходимостью быстро купировать проявления инфекционного заболевания и предупредить развитие его осложнений. Эмпирический выбор стартовой антибактериальной терапии - это выбор, основанный на предположении о наиболее вероятном возбудителе инфек- ционного заболевания и его предполагаемой (не доказанной!) чувствительности к выбранному антибактериальному препарату. Этот выбор основывается на опыте предыдущих лет относительно спектра чувствительности возбудителя к антибактериальным препаратам и не учитывает произошедшие со временем его изменения. Изменение спектра чувствительности и уровня устойчивости микробных популяций обусловливает необходимость определения их чувствительности перед назначением антибактериального препарата.

Наиболее частым методом определения антибиотикочувствительности возбудителей заболеваний является диско-диффузионный метод с использованием стандартных дисков, содержащих определенное количество антибиотика (в мкг). Реже на практике применяют количественные методы оценки чувствительности микроорганизмов к антибактериальным препаратам - метод серийных разведений в жидкой или плотной питательной среде, с помощью которых определяется минимальная подавляющая концентрация антибиотика (МПК). Для определения антибиотикочувствительности также используют Е-тест, представляющий собой пластиковую полоску с нанесенным градиентом концентрации антибиотика. Этот метод основан на дифффузии антибиотиков в агар и позволяет определять значение МПК.

В последние годы бактериологические лаборатории оснащаются автоматизированными системами для идентификации и определения антибиотикочувствительности микроорганизмов с использованием коммерческих тест-систем. При использовании классических методов определения чувствительности микроорганизмов к антибактериальным препаратам метода серийных разведений в жидкой или плотной питательной среде, а также диско-диффузионного метода ответ можно получить не ранее чем через 18 ч от начала исследования (а с учетом времени, необходимого для выделения чистых культур микроорганизмов, - через 48-72 ч) [2, 16]. Ускоренные методы определения чувствительности микроорганизмов к химиопрепаратам позволяют получить ответ уже спустя 2-6 ч от начала исследования чистых культур. Использование ускоренных методов и экспресс-методов определения чувствительности возбудителей гнойно-септических инфекций к антибиотикам позволяет раньше выбрать антибактериальный препарат и начать этиотропное лечение [2, 16]. Целесообразно одновременно проводить микроскопическое исследование клинических материалов с очагов поражения с окраской по методу Грама для быстрого выявления грамотрицательной микрофлоры. Выполнение этих исследований не только в стационаре, но и в амбулаторных условиях значительно повысит качество лечения и одновременно уменьшит возможности формирования устойчивых к противомикробным препаратам штаммов микроорганизмов $[9,15]$. 
В последние годы пенициллин и его дюрантные препараты редко применяют в терапии больных с инфекцией кожи и ее придатков, так как многие штаммы пиококков приобрели способность продуцировать фермент $\beta$-лактамазу (пенициллиназу), снижающую антибактериальную активность пенициллина. Продукция $\beta$-лактамаз является ведущим механизмом резистентности к $\beta$-лактамным антибиотикам среди возбудителей как внебольничных, так и госпитальных инфекций [9]. Компания АО «Астеллас Фарма» предложила комбинированный препарат, содержащий 875 мг амоксициллина и 125 мг клавулановой кислоты - ингибитора $\beta$-лактамаз - Флемоклав Солютаб ${ }^{\circledR}$ в лекарственной фрорме диспергируемые таблетки. Это высокоэффрективный препарат широкого спектра действия для лечения инфекций кожи и мягких тканей у детей и взрослых. Флемоклав Солютаб ${ }^{\circledR}$ воздействует на грамположительные (включая Staphylococcus spp. и Streptococcus spp., кроме резистентных к метициллину штаммов золотистого стафилококка) и грамотрицательные микроорганизмы (включая штаммы, продуцирующие $\beta$-лактамазы). В результате полноценного всасывания активных веществ диспергируемых таблеток в тонкой кишке эффективность действия препарата Флемоклав Солютаб ${ }^{\circledR}$ сопоставима с инъекционной формой антибиотиков. Взрослым и детям старше 12 лет препарат назначают в дозе 875/125 мг 2 раза в сутки. Он является препаратом выбора согласно ряду российских клинических рекомендаций. Побочные действия препарата Флемоклав Солютаб ${ }^{\circledR}$ такие же, как и у других лекарственных фрорм амоксициллина и клавулановой кислоты. Противопоказан препарат при нарушении функции печени при приеме амоксициллина/клавулановой кислоты в анамнезе, при инфекционном мононуклеозе, при почечной недостаточности (клиренс креатинина $\leq 30$ мл/мин), при повышенной чувствительности к амоксициллину, клавулановой кислоте и к другим $\beta$-лактамным антибиотикам, а также детям в возрасте до 12 лет с массой тела менее 40 кг (в данной дозировке) [9, 17]. Антибиотики $\beta$-лактамы (пенициллины, цефалоспорины, карбапенемы) обладают сенсибилизирующей активностью. Наиболее она выражена у пенициллинов, которые чаще других антибиотиков вызывают токсидермию. Поэтому нежелательно их назначать больным атопическим дерматитом или распространенной экземой для лечения вторичной пиодермии, так как пенициллины могут обострять течение основного заболевания. Целесообразно в таких случаях применить антибиотик из группы макролидов или антимикробный химиотерапевтический препарат из ряда тетрациклинов $[9,20]$.

Этиология подавляющего большинства нозологических фрорм пиодермии (импетиго, остиофолликулит, фролликулит, вульгарный сикоз, декальвирующий фолликулит, фрурункул, ффурункулез, карбункул, гидраденит, паронихия, эктима, рожистое воспаление, целлюлит) однородна. Их основными возбудителями, особенно внебольничной инфекции, являются Staphylococcus aureus и Streptococcus pyogenes. Существенно реже выделяют другие стрептококки, синегнойную палочковидную бактерию, энтеробактерии. Эти микроорганизмы являются возбудителями преимущественно нозокомиальной (внутрибольничной) инфекции и обычно развиваются у больных с тяжелыми инфекциями или с подавленным иммунитетом [3-5, 7, 13-15].

В настоящее время больным пиодермией амбулаторно и в стационаре могут назначить антибиотик из групп цефалоспоринов или макролидов или противомикробный препарат фрторхинолонового ряда, реже - антибиотик тетрациклинового ряда. Это соответствует Клиническим рекомендациям по лечению больных пиодермией Российского общества дерматовенерологов 2015 г. Из антибиотиков цефалоспоринового ряда, которые оказывают бактерицидное действие на чувствительные микроорганизмы, обычно применяют полусинтетические цефалоспорины I-II поколения (цефразолин, цефрадроксил, цефуроксим) [17]. В тех случаях, когда возбудителями являются (или входят в состав смешанной микробной флоры) грамотрицательные микроорганизмы (Pseudomonas aeruginosa, Enterobacter spp., Proteus vulgaris), целесообразно выбирать противомикробный препарат, оказывающий подавляющее воздействие и на грамотрицательную микрофлору (цефалоспорины III-IV поколения, карбапенемы, ванкомицин, амикацин и др.). Ассоциации микроорганизмов чаще выделяют у больных с хронической язвенной пиодермией, паронихией, фолликулитами «горячей ванны», инфицированными ожогами, травмами и пролежнями. Цефалоспорины не следует назначать пациентам с тяжелыми формами аллергии к пенициллину в анамнезе, так как риск перекрестной сенсибилизации при этом достаточно высок (до 10\%) $[9,17]$.

Антибиотики-макролиды обладают широким спектром антибактериального действия и считаются одними из наиболее безопасных. Первым природным препаратом этого ряда был эритромицин, полученный в 1952 г. Затем были открыты спирамицин, олеандомицин, мидекамицин, джозамицин и полусинтетические макролиды - кларитромицин, рокситромицин и азитромицин (1983 г.). Антибиотики этого ряда по спектру противомикробного действия напоминают эритромицин, однако отличаются лучшей фрармакокинетикой, биодоступностью и переносимостью [15, 17-19]. Спектр действия их распространяется на грамположительные кокки (стрептококки, стафилококки) и внутриклеточные возбудители. Макролиды не разрушаются $\beta$-лактамазами и сравнительно редко вызывают аллергические реакции. Частое и не всегда обоснованное применение эритромицина достаточно быстро привело к появлению эритромициноустойчи- 
вых штаммов возбудителей, особенно стафилококков. Это обусловило значительное снижение частоты применения эритромицина в клинической практике. Антибактериальное действие макролидов основано на нарушении синтеза рибосомальных белков микробной клетки, что приводит к подавлению процесса воспроизведения возбудителя. Они дают в основном бактериостатический эффрект.

Макролиды хорошо распределяются в организме, они способны преодолевать гистогематический барьер (за исключением гематоэнцефалического). При распределении в организме они накапливаются не в кровяном русле, а в тех органах и тканях, где протекает воспалительный процесс, создавая именно в этих очагах высокие концентрации препарата [17]. Это обусловлено еще и тем, что макролиды наряду с противомикробным оказывают умеренное противовоспалительное действие. Активируя клетки макрофагального ряда, они способны проникать в них и при миграции фрагоцитирующих клеток (моноциты, макрофраги, эпителиоидные и многоядерные гигантские клетки) в очаги воспаления поступать туда вместе с ними. Макролиды, как природные, так и полусинтетические, по сравнению с другими антибиотиками оказывают минимальное влияние на нормальную микрофрлору организма человека. Поэтому джозамицин рассматривается не только как высокоэффективный, но и как хорошо переносимый антибиотик. Нежелательные реакции при его приеме в целом встречаются редко и не превышают 5\%. Наиболее частыми побочными эфффектами являются симптомы со стороны желудочно-кишечного тракта (тошнота, тяжесть в эпигастральной области), которые, как правило, выражены умеренно, не требуют отмены препарата и быстро проходят при приеме лекарств после еды [9, 17, 18, 20].

Из группы макролидов препаратом выбора антибактериальной терапии больных пиодермией может являться джозамицин. Джозамицин представлен на рынке России препаратом Вильпрафенн ${ }^{\circledR}$ в лекарственной фрорме таблетки по 500 мг. Джозамицин является природным 16-членным макролидом, который продуцируется актиномицетом Streptomyces narbonensis var. josamyceticus. Механизм его действия связан с нарушением синтеза белка в микробной клетке вследствие обратимого связывания с 50S-субъединицей рибосомы. В терапевтических концентрациях, как правило, оказывает бактериостатическое действие, замедляя рост и размножение бактерий. Джозамицин обладает высокой активностью против грамположительных бактерий S. pyogenes, S. aureus, Corynebacterium diphtheriae, Corynebacterium minutissimum, Propionibacterium acnes, Bacillus anthracis, Clostridium spp.; грамотрицательных бактерий Neisseria meningitidis, Neisseria gonorrhoeae, Moraxella catarrhalis, Brucella spp., Legionella spp., Helicobacter pylori, Campilobacter jejuni и др., а также в отношении
Chlamydia spp., Mycoplasma spp., Ureaplasma spp., Treponema pallidum, Borrelia burgdorferi. Джозамицин не активен в отношении энтеробактерий, поэтому незначительно влияет на микрофлору желудочно-кишечного тракта [17]. Резистентность к джозамицину встречается реже, чем к эритромицину, кларитромицину и азитромицину.

После приема внутрь макролиды частично разрушаются под действием соляной кислоты желудка. В наибольшей степени это касается эритромицина и олеандомицина. Джозамицин имеет повышенную устойчивость к соляной кислоте желудочного сока. После приема внутрь джозамицин быстро абсорбируется из желудочно-кишечного тракта. Прием пищи не влияет на его биодоступность. Связывание с белками плазмы составляет около 15\%. Джозамицин хорошо распределяется в органах и тканях (за исключением головного мозга), создавая концентрации, превышающие плазменную. Особенно высокие концентрации препарата определены в легких, миндалинах, слюне, поте и слезной жидкости. Джозамицин проходит плацентарный барьер и секретируется в грудное молоко. Рекомендованная суточная доза препарата для взрослых и подростков в возрасте старше 14 лет составляет 1-2 г в 2-3 приема $[9,17,18]$.

Как свидетельствуют сравнительные исследования, при инфекции кожи и ее придатков среди антибиотиков, применяющихся в амбулаторной практике, наиболее эффективны макролиды нового поколения, в первую очередь 16- и 15-членные (джозамицин, рокситромицин, азитромицин) [12, 17, 21, 22]. Высокая терапевтическая активность джозамицина в лечении пиодермии была подтверждена как у взрослых, так и у детей $[15,21,22]$. Препарат обладает хорошей переносимостью, оказался более эффективным по сравнению с эритромицином.

Если рассматривать тетрациклины, то в настоящее время для лечения больных гнойной инорекции кожи и ее придатков, их используют редко. Это связано с возрастающим количеством резистентных к ним штаммов микроорганизмов (из чего следует их низкая терапевтическая активность), а также с наличием серьезных побочных эффректов. Из препаратов этого ряда нередко используют доксициклина моногидрат - антибиотик, полученный синтетическим путем из окситетрациклина. Он длительно действует, имеет широкий спектр противомикробного (бактериостатического) действия. В России препарат под названием Юнидокс Солютаб ${ }^{\circledR}$ доступен в лекарственной форме диспергируемые таблетки с содержанием 100 мг доксициклина моногидрата. Взрослым в первый день лечения назначают 200 мг в сутки в один или два приема, в последующие дни лечения - по 100 мг в сутки в один прием. Препарат предпочтительно принимать во время еды. При инфекции, вызванной Streptococcus 
pyogenes, продолжительность лечения составляет не менее 10 дней. Доксициклин относится к липофильным тетрациклинам, поэтому хорошо распространяется во многих тканях и жидкостях. Доксициклина моногидрат относится к длительно действующим производным тетрациклина, так как его период полувыведения составляет 16-18 ч. Он практически полностью всасывается, достигая высокого уровня в сыворотке при относительно низких дозах (доза 100 мг эквивалентна дозе 500 мг кратковременно действующего тетрациклина) [9]. Он подавляет синтез белка в микробной клетке путем взаимодействия с 30S-субъединицей рибосом. Активен в отношении большинства грамположительных и грамотрицательных аэробных и анаэробных бактерий, включая Staphylococcus spp. и Streptococcus spp., Propionibacterium acnes. Не активен в отношении Acinetobacter spp., Proteus spp., Pseudomonas spp., Serratia spp., Providencia spp., Enterococcus spp. [17]. Следует принимать во внимание возможность у ряда возбудителей приобретенной устойчивости к доксициклину, которая часто является перекрестной внутри группы тетрациклинов. В сериях исследований показано, что 20-40\% штаммов Streptococcus pyogenes и 50\% штаммов Staphylococcus aureus стали устойчивыми к тетрациклинам. Однако доксициклин обладает в 2-4 раза большей активностью in vitro, чем тетрациклин и окситетрациклин [9]. По данным Т.Я. Пхакадзе и соавт., устойчивость культур Staphylococcus aureus, полученных в стационаре от травматолого-ортопедических больных, к доксициклину была всего 4\% [7]. Пища уменьшает абсорбцию тетрациклинов, так как все они образуют неактивные комплексы с ди- или тривалентными катионами. Поэтому тетрациклины нельзя назначать одновременно с кальцием, магнием и алюминием в антацидах, с молоком или железосодержащими препаратами. Все тетрациклины проникают через плаценту и накапливаются в костях и зубах плода, вызывая гипоплазию эмали с последующей серо-коричневой или желтой окраской зубов и депрессией роста скелета у недоношенных младенцев [9]. Юнидокс Солютаб ${ }^{\circledR}$ активно применяют при лечении больных вульгарными угрями (в составе комплексной терапии) и папуло-пустулезной формой розацеа $[15,17]$. В качестве препарата резерва его используют после укуса кошки или собаки для лечения гнойных осложнений (флегмоны), обусловленных грамотрицательной коккобациллой Pasteurella multocida самостоятельно или в сочетании со Staphylococcus aureus, Streptococcus viridans, Fusobacterium spр. и др.

Следует помнить, что тетрациклины противопоказаны при беременности, детям и пациентам с печеночной или почечной недостаточностью, при порфирии и повышенной чувствительности к антибиотикам этой группы [17].

Сульфаниламидные препараты, как самостоятельно, так и в сочетании с триметопримом, который значительно потенцирует их действие, в настоящее время в лечении больных пиодермией применяют редко. Это связано с рядом фракторов: появились в значительном количестве устойчивые к ним бактерии, созданы более активные антимикробные препараты с менее выраженным побочным действием, отсутствует клинический эффрект у больных с иммунодефицитным состоянием $[14,15,17]$.

Продолжающиеся изменения чувствительности микробных популяций к противомикробным препаратам обусловливают необходимость определения спектра чувствительности патогенов перед назначением стартовой антибактериальной терапии. Использование ускоренных и экспресс-методов определения чувствительности инфекционных возбудителей к антибактериальным препаратам позволяет выбрать действенный антибактериальный препарат для назначения стартовой этиотропной терапии. При выполнении этого условия существенно повысится эффективность лечения больных пиодермией и снизится возможность формирования устойчивости патогенных микроорганизмов к антибактериальным препаратам.
1. Aragüés M., González-Arriba A. Primary cutaneous infections due to Staphylococcus and Streptococcus. Actas Dermosifiliogr 2007; 98 (S1): 4-14.

2. Levi M. I., Suchkov Ju.G., Sliskova V.G. Express-method of choice of the preferable antibiotics of purulent septic infections treatment. Dezinfectsionnoe delo 1999; (4): 29-33. [Леви М.И., Сучков Ю.И., Слизкова В.Г. Экспресс-метод отбора предпочтительных антибиотиков для лечения больных гнойно-септическими инфекциями. Дезинфекционное дело 1999; (4): 29—33.]

\section{Литература}

3. Mitrokhin S. D., Sutormina T. M., Ritchik L. A., Nonikov V. E., Petrov M. V., Minaev V.I. Antibiotic resistance of nosocomial strains in a multi-field hospital. Klini Vestn 1998; (4): 17-19. [Митрохин С. Д., Сутормина Т. М., Ритчик Л.А., Ноников В.Е., Петров М. В., Минаев В.И. Антибиотикорезистентность госпитальных штаммов в многопрофильной больнице. Клин вестн 1998; (4): 17-19.]

4. Sidorenko S. V. Clinical significance of Pseudomonas aeruginosa. Klin pharmakol 2003; (2): 12-17. [Сидоренко С.В. Клиническое значение Pseudomonas aeruginosa. Клин фармакол тер 2003; (2): 12—17.]
5. Yakovlev S. V., Suvorova M.P. Antibacterial treatment of polyresistant nosocomial infections. Clin Pharmacol Ther 2011; 20 (2): 24-34. [Яковлев С.В., Суворова М.П. Обоснование антибактериальной терапии нозокомиальных инсекций, вызванных полирезистентными микроорганизмами. Клин фрармакол тер 2011; 20 (2): 24-34.]

6. Empinotti J. C., Uyeda H., Ruaro R. T., Galhardo A. P., Bonatto D. C. Pyodermitis. An Bras Dermatol 2012 ; 87 (2): 277-284. 
7. Pkhakadze T.Ya., Okropiridze G.G., Malysheva E. S. Choice of Antibacterial Agents for Prevention and Treatment of Infectious Complications in Traumatologic and Orthopaedic Patients by Microbiologic Monitoring. Vestn Traumat Orthop 2009; (4): 73-78.] Пхакадзе Т.Я., Окропиридзе Г.Г., Малышева Э.С. Выбор антибактериальных средств для просилактики и лечения инфекционных осложнений у травматолого-ортопедических больных на основе микробиологического мониторинга. Вестн травматол ортопед 2009; (4): 73-78.]

8. Jansen G., Barbosa C., Schulenburg H. Experimental evolution as an efficient tool to dissect adaptive paths to antibiotic resistance. Drug Resist Updat 2014. pii: S1368-7646(14)00004-1. doi: 10.1016/j.drup.2014.02.002.

9. Katsambas A. D., Lotti T. M. European Handbook of Dermatological Treatments. 2nd Edition. Berlin Heidelberg: Springer-Verlag; 2003. [Европейское руководство по лечению дерматологических заболеваний. Под ред. А. Д. Кацамбаса, Т. М. Лотти. Пер. с англ. М: МЕДпресс-инфрорм, 2008; 727.$]$

10. Aldred K. J., Kerns R. J., Osheroff N. Mechanism of Quinolone Action and Resistance. Biochemistry 2014; 53 (10): 1565_-1574.

11. Shanmugam P., Meenakshisundaram J., Jayaraman P. blaKPC gene Detection in Clinical Isolates of Carbapenem Resistant Enterobacteriaceae in a Tertiary Care Hospital. J Clin Diagn Res 2013; 7 (12): 2736-2738.

12. Belkova Yu. A., Rachina S. A. Modern approaches to antimicrobial stewardship in multi-bed hospitals: international trends and domestic experience. Clin Pharmacol Ther 2012; 21 (2): 34-41. [Белькова Ю. А., Рачина С.А. Современные подходы к оптимизации антибактериальной терапии в многопрофильных стационарах: мировые тенденции и отечественный опыт. Клин фрармакол тер 2012; 21 (2): 34—41.]
13. Guchev I. A., Sidorenko S. V., Frantsuzov V. N. Rational Antimicrobial Chemotherapy of Skin and Soft Tissue Infections. Antibiot Chemother 2003; 48 (10): 25-31. [Гучев И. А., Сидоренко С.В., Французов В.Н. Рациональная антимикробная химиотерапия инфекций кожи и мягких тканей. Антибиот. Химиотер 2003; 48 (10): 25-31.]

14. Vinogradova T. V., Krylov A. A., Taits B. M. Antibiotic treatment (modern principles and experience of antibiotic use at the multifield hospital's units). Nov SPb Vrach Ved 2009; (2): 65-71. [Виноградова Т.В., Крылов А. А., Тайц Б. М. Антибиотикотерапия (современные принципы и опыт применения в отделениях многопрофильной больницы). Нов СПб Врач Вед 2009; (2): 65-71.]

15. Khaldin A. A. Rational antibiotic therapy in the practice of dermatovenereologist. Rus med zhurn 2005; 13 (5): 273-277. [Халдин А. А. Рациональная антибактериальная терапия в практике дерматовенеролога. Рус мед журн 2005; 13 (5): 273—277.]

16. Gudkova E. I., Adarchenko A. A., Skorokhod G. A., Lastochkina T. M. Express-methods for the detection of antibiotic susceptibilty and antibiotic resistance of microorganisms. Zdravookhranenie 2006; 5: 22-24. [Гудкова Е.И., Адарченко А.А., Скороход Г.А., Ласточкина Т. М. Ускоренные и экспрессметоды определения чувствительностиустойчивости микроорганизмов к антибиотикам. Здравоохранение 2006; 5: 2224.]

17. Справочник ВИДАЛЬ. Лекарственные препараты в России: Справочник. М: ЮБМ Медика Рус 2013: 1640.

18. Sinopal'nikov A. I., Andreeva I. V., Stetsuyk 0.U. The Safety of macrolide antibiotics: critical analysis. Clin Med 2012; 90 (3): 2330. [Синопальников А. И., Андреева И.В., Стецюк О.У. Безопасность макролидных антибиотиков: критический анализ. Клин мед 2012; 90 (3): 23—30.]
19. Yakovlev S. V. Fluoroquinolones: an overview of antimicrobial activity, pharmacokinetics, clinical indications and adverse effects. Klin Vestn 1996; 4: 22-26. [Яковлев С. В. Фторхинолоны: обзор антимикробного действия, фрармакокинетических свойств, клинического применения и побочных эффректов. Клин вестн 1996; 4: 22-26.]

20. Parsad D., Pandhi R., Dogras S. A guide to selection and appropriate use of macrolides in skin infection. Am J Clin Dermatol 2003; (4): 389-397.

21. Volkova E. N., Butov Yu.S. Josamycin in chronic pyoderma treatment. Ros Zhurn Kozh Ven Bol 2000; (5): 23-25. [Волкова Е. Н., Бутов Ю. С. Джозамицин в терапии гнойничковых заболеваний кожи. Рос журн кож вен бол 2000; (5): 23-25.]

22. Khamaganova I. V. Pyoderma treatment in children with Wilprafen (Josamycin). Ros vestn Perinatol i Pediatr 2001; 46 (3): 55-56. [Хамаганова И.В. Лечение вильпрасеном (джозамицином) пиодермитов у детей. Рос вестн перинатол и педиатр 2001; 46 (3): 55-56.]

23. Padejskaya E. N. Fluoroquinolone antimicrobials: toxicity, safety, adverse reactions, contraindications. Rus Med Zhurn 1999; 7 (10): 470-476. [Падейская Е. Н. Антимикробные препараты группы фрторхинолонов: токсичность, безопасность, побочные реакции, противопоказания. Рус мед журн 1999; 7 (10): 470-476.]

24. Padejskaya E. N., Yakovlev V.P. Fluoroquinolone antimicrobials in clinical practice. M: Lagota 1998. [Падейская Е. Н., Яковлев B.П. Антимикробные препараты группы фрторхинолонов в клинической практике. М.: Лагота, 1998.]

об авторах:

Михеев Н. Г. - к.м.Н., доцент кафедры дерматовенерологии с клиникой ФГБОу По ПсПбГмУ им. академика

И. П. Павлова Минздрава России

Е.В. Соколовский - д.м.н., профессор, зав. кафедрой дерматовенерологии с клиникой ФГБОУ По ПСПбГМУ им. академика

И. П. Павлова Минздрава России

А. М. Савичева — профессор, доктор медицинских наук, зав. лабораторией микробиологии ФГБНУ «НИИ акушерства,

гинекологии и репродуктологии им. Д. О. Отта», Санкт-Петербург

\section{Конфликт интересов}

Авторы заявляют об отсутствии потенциального конфликта интересов, требующего раскрытия в данной статье 